\title{
Pyrophen Produced by Endophytic Fungi Aspergillus sp Isolated from Piper crocatum Ruiz \& Pav Exhibits Cytotoxic Activity and Induces S Phase Arrest in T47D Breast Cancer Cells
}

\author{
Puji Astuti $^{1 *}$, Willy Erden ${ }^{2}$, Wahyono ${ }^{1}$, Subagus Wahyuono ${ }^{1}$, Triana Hertiani ${ }^{1}$
}

\begin{abstract}
Ethyl acetate extracts obtained from culture of endophytic fungi Aspergillus sp isolated from Piper crocatum Ruiz \& Pav, have been shown to possess cytotoxic activity against T47D breast cancer cells. Investigations were here conducted to determine bioactive compounds responsible for the activity. Bioassay guided fractionation was employed to obtain active compounds. Structure elucidation was performed based on analysis of LC-MS, ${ }^{1} \mathrm{H}$-NMR, ${ }^{13} \mathrm{C}-\mathrm{NMR}$, COSY, DEPT, HMQC, HMBC data. Cytotoxity assays were conducted in 96 well plates against T47D and Vero cell lines. Bioassay guided isolation and chemical investigation led to the isolation of pyrophen, a 4-methoxy-6-(1'-acetamido-2'-phenylethyl)-2H-pyran-2-one. Further analysis of its activity against T47D and Vero cells showed an ability to inhibit the growth of T47D cells with IC50 values of $9.2 \mu \mathrm{g} / \mathrm{mL}$ but less cytotoxicity to Vero cells with an $\mathrm{IC}_{50}$ of $109 \mu \mathrm{g} / \mathrm{mL}$. This compound at a concentration of $400 \mathrm{ng} / \mathrm{mL}$ induced $S$-phase arrest in T47D cells.
\end{abstract}

Keywords: Aspergillus sp - cytotoxic - T47D - pyrophen - S - phase arrest

Asian Pac J Cancer Prev, 17 (2), 615-618

\section{Introduction}

Breast cancer is the major cause of death from cancer in women with about 508000 women was estimated died from this disease in 2011 (IARC, 2012; WHO, 2013). The high incidence in developed countries is also occurring in developing countries and the number is increasing due to in part the increase in life expectancy and changes in lifestyles. In addition, the lack of early detection program and inadequate diagnosis and medical facilities result in low survival rates (IARC, 2008). Despite this huge global health problem, the available conventional chemotherapeutic agents possess side effects to normal cells. Therefore, there is an urgent need to discover and develop new compounds to treat breast cancer.

Exploration of endophytic fungi have gained increased interest among scientist as these microorganisms produce biologically-active compounds with therapeutic values (Zhao et al., 2009; Santiago et al., 2012; do Nascimento et al., 2015; Richardson et al., 2015). Many of the compounds have been reported to produce bioactive compounds against various types of cancer cell lines (Chui et al., 2011; Zheng et al., 2013; Zhu et al., 2013; Chen et al., 2015; Wang et al., 2015). Previous studies in our laboratory demonstrated that ethyl acetate extract obtained from the culture of Aspergillus sp isolated from the stem of
Piper crocatum Ruiz.\& Pav. exhibited cytotoxic activities against T47D cells (Astuti, et al., 2014). This study aims to explore bioactive compounds responsible for the activities.

\section{Materials and Methods}

\section{Materials}

Potato Dextrose Agar (PDA), Dextrose were purchased from Oxoid. RPMI 1640, Fetal Bovine Serum, Penicillin - Streptomycin, Fungizon, Sodium bicarbonate, were supplied from Gibco. HEPES (4-(2-hydroxyethyl)-1piperazineethanesulfonic acid) (Invitrogen), PhosphateBuffered Saline (PBS), propidium iodide (PI) (SigmaAldrich), MTT (Sigma-Aldrich). Silica gel $\mathrm{F}_{254}$, Silica gel $60 \mathrm{PF}_{254}$ containing gypsum, DMSO, chloroform, n-hexane, ethyl acetate (Merck). Endophytic fungi Aspergillus sp isolated from Piper crocatum Ruiz \& Pav (Culture collection of Pharmaceutical Biology Department, Faculty of Pharmacy, UGM).

\section{Semipolar extraction of fermentation cultures}

The endophytic fungi grown in PDA was inoculated in $1000 \mathrm{~mL}$ potato dextrose broth in Erlenmeyer flasks and incubated at room temperature and $160 \mathrm{rpm}$ for 10 days. The crude fermentation broth were filtered with Whatman filter paper and followed by centrifugation at $4000 \mathrm{r} / \mathrm{min}$ 
Puji Astuti et al

for 5 min. Liquid supernatant was extracted with an equal volume of ethyl acetate thrice. The ethyl acetate fractions were then evaporated under reduced pressure to yield an ethyl acetate extract.

\section{Bioasay guided isolation of cytotoxic compound}

Ethyl acetate extract was partitioned using preparative thin layer chromatography (stationary phase=silica gel $60 \mathrm{PF}_{254}$; mobile phase=chloroform: methanol=9:1) to obtain five fractions to be tested for cytotoxic activities. The most cytotoxic fraction with the highest score of selectivity index was further purified using preparative thin layer chromatography (stationary phase: silica gel $60 \mathrm{PF}_{254}$; mobile phase: ethyl acetate: $\mathrm{n}$-hexane=9:1) to obtain bioactive compounds.

\section{Cytotoxic activity}

T47D (Human ductal breast epithelial tumor cell line) and Vero (cell line) were cultured in RPMI 1640 supplemented with $10 \%$ heat inactivated fetal bovine serum (FBS), $1 \%$ penicillin/streptomycin and $1 \mu \mathrm{g} / \mathrm{mL}$ fungizon. The cultures were incubated in a humidified incubator at $37^{\circ} \mathrm{C}$ with $5 \% \mathrm{CO}_{2}$. A hundred $\mu \mathrm{l}$ of media containing $5 \times 10^{3}$ cells was added to 96 -well plate and incubated for 48 hours until $70 \%-80 \%$ confluent. Extracts or isolates were added to the wells at various concentrations followed by 24 hours of incubation. The treated cells were gently washed with pre-warmed $1 \mathrm{X}$ PBS, and $100 \mu \mathrm{l}$ media containing $0.5 \mathrm{mg} / \mathrm{mL}$ MTT was added to the well. The cells were incubated for 4 hours at $37^{\circ} \mathrm{C}$ and the reaction was stopped by adding $100 \mu \mathrm{L}$ of $10 \%$ SDS. The plates were read in microplate reader (Bio-Rad) at $595 \mathrm{~nm}$. Data generated were used to plot a dose-response curve of which the concentration of fractions/isolates required to kill $50 \%$ of cell population $\left(\mathrm{IC}_{50}\right)$ was determined. Selectivity index was calculated by dividing $\mathrm{IC}_{50}$ values of fractions/isolates against T47D cells towards $\mathrm{IC}_{50}$ values of fractions/compounds against normal Vero cells.

\section{Cell cycle analysis}

Three $\mathrm{mL}$ of media containing $5 \times 10^{5} \mathrm{~T} 47 \mathrm{D}$ cells were inoculated in six well plates and incubated for 24 hours prior to treatment with bioactive compound. The cells were treated with various concentrations of bioactive compound and further incubated for 16 hours. The cells were harvested and re-suspended in PBS containing $50 \mu \mathrm{g} /$ $\mathrm{mL}$ propidium iodide and ready for cell cycle distribution analysis using flow cytometer BD FACSCaliburTM (BD Biosciences).

\section{Structure elucidation of cytotoxic compound}

Structure elucidation was conducted based on analysis of LC-MS, 1H-NMR, 13C-NMR, COSY, DEPT, HMQC,
HMBC data. Phyrophen: white crystalline powder; ESI-MS m/z 288.2834 [M+H]+ (calcd for $\mathrm{C}_{16} \mathrm{H}_{17} \mathrm{NO}_{4}$, 288.2834); $1 \mathrm{H}$ and 13C NMR in DMSO-d6, see Table 2.

\section{Results}

Bioassay guided isolation and bioactivity testing

Ethyl acetate extract was partitioned by preparative thin layer chromatography to obtain five fractions. These fractions were tested for cytotoxicity against T47D and Vero cells. Among five fractions tested fraction 4 was found to have the highest selectivity index (Table 1). This fraction contains a bioactive compound having 95.97\% purity as determined by Liquid Chromatography (Figure 1). This compound exhibited $\mathrm{IC}_{50}$ of $9.2 \mu \mathrm{g} / \mathrm{mL}$ against T47D and $\mathrm{IC}_{50}$ of $109.0 \mu \mathrm{g} / \mathrm{mL}$ against normal Vero cells. Further cell cycle analysis demonstrated that this compound induced S-phase arrest when it was administered at $400 \mathrm{ng} / \mathrm{mL}$ (Figure 2).

\section{Structure elucidation of the cytotoxic compound}

LC-MS peak of isolate appeared at $T_{R} 3.24 \mathrm{~min}$ having a $95.97 \%$ of purity. Molecular weight of $287 \mathrm{amu}$ was revealed by analysing a pseudomolecular ion peak at $\mathrm{m} / \mathrm{z} 288.2834$ having a $100 \%$ abundance referred to $[\mathrm{M}+\mathrm{H}]+$, which is confirmed by the presences of peaks of $[\mathrm{M}+\mathrm{Na}]+$ at $\mathrm{m} / \mathrm{z} 310.2870 ;[2 \mathrm{M}+\mathrm{H}]+$ at $\mathrm{m} / \mathrm{z} 575.6121$ and $[2 \mathrm{M}+\mathrm{Na}]+$ at 597.6084 .

${ }^{1} \mathrm{H}-\mathrm{NMR}$ data showed that the isolate contains at least 17 protons distributed from the most upfield region at $\delta 1.78(3 \mathrm{H}, \mathrm{s})$ referred to a $-\mathrm{CH} 3$ having an electronwithdrawing neighbour, up to the most down field proton, at $\delta 8.49\left({ }^{1} \mathrm{H}, \mathrm{d}, \mathrm{J}=8.4 \mathrm{~Hz}\right)$. Evaluation of splitting pattern and coupling constants suggests two isolated substructures which is confirmed by the ${ }^{1} \mathrm{H}-{ }^{1} \mathrm{H}$ COSY measurement, i.e $=:-\mathrm{CH} 2-\mathrm{CH}-\mathrm{NH}-$ and a monosubstituted benzene.

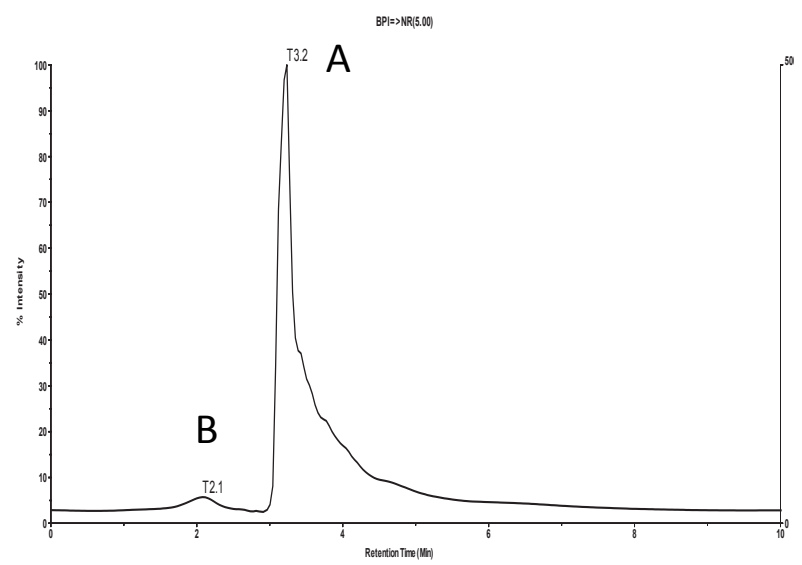

Figure 1. Liquid Chromatography Profiles of Fraction 4 Containing Bioactive Compound. Volume of injection $20 \mu 1$, Flow $1 \mathrm{~mL} / \mathrm{min}$, Eluent $\mathrm{MeOH}+$ water $=95+5$

Table 1. IC $_{50}$ Values and Selectivity Index of Fractions Generated from Ethyl Acetate Extract

\begin{tabular}{lccccc}
\hline Fractions & F1 & F2 & F3 & F4 & F5 \\
\hline $\mathrm{IC}_{50}(\mu \mathrm{g} / \mathrm{mL})$ against T47D cells & 142.9 & 82.6 & 6.9 & 9.2 & 48.4 \\
$\mathrm{IC}_{50}(\mu \mathrm{g} / \mathrm{mL})$ against Vero cells & 439.5 & 308.4 & 53.8 & 109 & 338.8 \\
Selectivity Index & 3.1 & 3.7 & 7.8 & 11.8 & 7 \\
\hline
\end{tabular}


Pyrophen Isolated from Piper crocatum Ruiz \& Pav Exhibits Cytotoxic Activity and Induces S Phase Arrest in T47D Cells

Table 2. NMR data of Isolate measured by ${ }^{1} \mathrm{H}-\mathrm{NMR}$ and ${ }^{13} \mathrm{C}$-NMR in DMSO-d 6 (500 MHz)

\begin{tabular}{|c|c|c|}
\hline Atom No. & $\begin{array}{l}\delta \mathrm{C}(\mathrm{ppm}) \\
\text { DEPT }\end{array}$ & $\begin{array}{c}\delta \mathrm{H}(\mathrm{ppm}), \text { integration, } \\
\text { splitting pattern and } \mathrm{J} \\
\text { value }(\mathrm{Hz})\end{array}$ \\
\hline 2 & $22.41, \mathrm{CH} 3$ & $1.78,3 \mathrm{H}, \mathrm{s}$ \\
\hline 1 & $169.03, \mathrm{C}=\mathrm{O}$ & - \\
\hline $\mathrm{NH}$ & - & $8.49,1 \mathrm{H}, \mathrm{d}, 8.4$ \\
\hline$\alpha$ & $52.98, \mathrm{CH}$ & $\begin{array}{c}4.76,1 \mathrm{H}, \delta \delta \delta, 5.8,9.1 \text {, } \\
8.4\end{array}$ \\
\hline$\delta \alpha$ & $37.85, \mathrm{CH} 2$ & $2.89,1 \mathrm{H}, \delta \delta, 13.7,9.1$ \\
\hline$\delta \delta$ & & $3.01,1 \mathrm{H}, \delta \delta, 13.7,5.8$ \\
\hline $2^{\prime}$ & $163.78, \mathrm{C}=\mathrm{O}$ & - \\
\hline 5 , & $88.01, \mathrm{CH}$ & $5.57,1 \mathrm{H}, \mathrm{d}, 2.6$ \\
\hline $4^{\prime}$ & $170.77, \mathrm{C}=\mathrm{O}$ & - \\
\hline $3^{\prime}$ & $99.40, \mathrm{CH}$ & $6.05,1 \mathrm{H}, \mathrm{d}, 1.9$ \\
\hline 2 ' & $163.21, \mathrm{O}-\mathrm{C}=\mathrm{C}-$ & - \\
\hline $\mathrm{OCH} 3$ & $56.48, \mathrm{CH} 3$ & $3.78,3 \mathrm{H}, \mathrm{s}$ \\
\hline $2 ", 6 "$ & $128.29,-\mathrm{CH}=$ & $7.22,2 \mathrm{H}, \mathrm{d}, 7.1$ \\
\hline $3 ", 5 ”$ & $129.05,-\mathrm{CH}=$ & $7.27, \mathrm{t}, 7.1$ \\
\hline $4 "$ & $126.57,-\mathrm{CH}=$ & $7.18, d, 7.1$ \\
\hline $1 "$ & 137.27. C & - \\
\hline
\end{tabular}
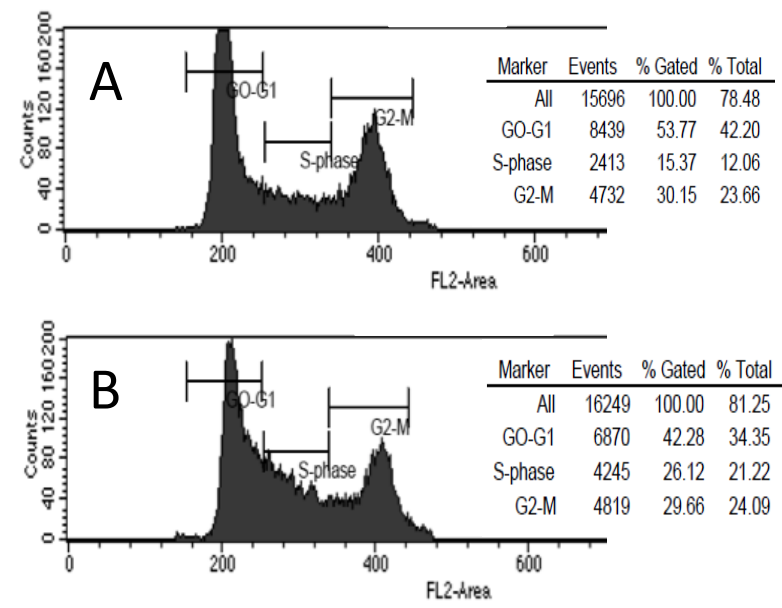

Figure 2. Cell Cycle Distribution of T47D Cells without (A) and Treated with $400 \mathrm{ng} / \mathrm{mL}$ of Bioactive Compound (B). T47D cells were inoculated in 6 well plate followed by $16 \mathrm{~h}$ incubation with and without bioactive compound in humidified incubator at $37^{\circ} \mathrm{C}, 5 \% \mathrm{CO}_{2}$. The cells were analysis for cell cycle distribution by flow cytometry

${ }^{13} \mathrm{C}$-NMR resolved 14 carbon resonance peaks of which DEPT analyses revealed the presence of 1 secondary carbon at $\delta 37.85 ; 5$ quartenary carbons at $\delta$ 170.77; 169.08; 163.78; and 163.21. ${ }^{1} \mathrm{H}-{ }^{13} \mathrm{C}$ HMQC analyses distinguished $2 \mathrm{CH} 3 \mathrm{~s}$ at $\delta 22.41$ and 56.48, while the rest 6 peaks reffered to CHs. Each peaks at $\delta 129.06$ and 128.30 represents the presence of $2 \mathrm{CHs}$ having identical environment. These peaks together with a $\mathrm{CH}$ peak at $\delta 126.58$ and $\delta 137.27$ suggested the carbon resonances of a monosubstituted benzene. The presence of - $\mathrm{CH} 2-\mathrm{CH}-\mathrm{NH}$ - was confirmed by the ${ }^{1} \mathrm{H}-{ }^{13} \mathrm{C}$ HMBC analyses, which at the same time proposed the substructure as shown in Figure 3.

Different effect of the protons environment of the $\mathrm{CH}_{2}$ resulted two adjacent peaks at $\delta 2.89(1 \mathrm{H}, \mathrm{dd}, \mathrm{J}=13.7$,

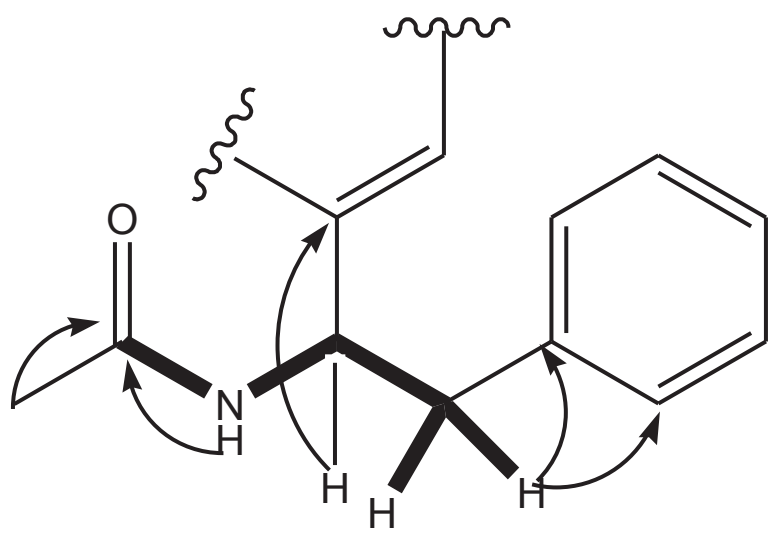

Figure 3. Important HMBC and COSY data of the proposed substructure. ${ }^{1} \mathrm{H}-{ }^{13} \mathrm{C} \mathrm{HMBC} \rightarrow{ }^{1} \mathrm{H}-{ }^{1} \mathrm{H}$ COSY

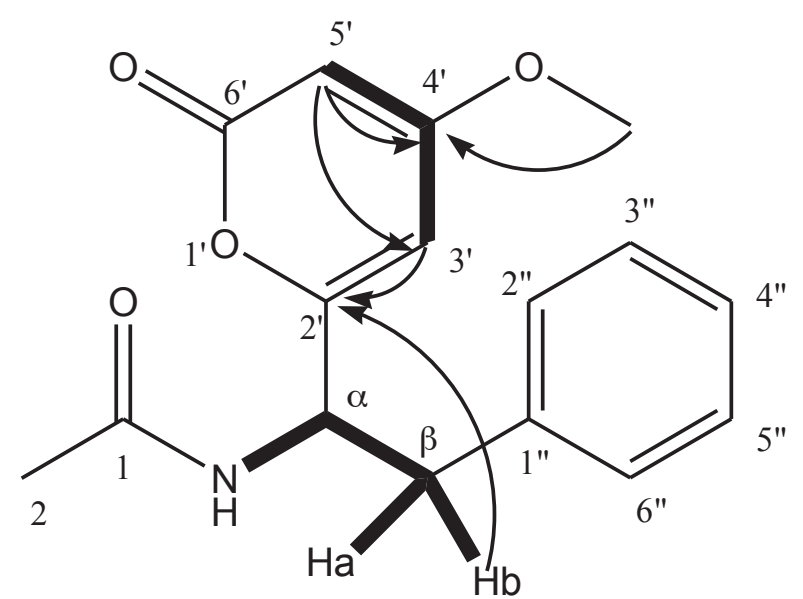

Figure 4. Important HMBC and COSY data confirming the chemical structure of the isolate. ${ }^{1} \mathrm{H}-{ }^{13} \mathrm{C} \mathrm{HMBC} \rightarrow$ ${ }^{1} \mathrm{H}-{ }^{1} \mathrm{H} \operatorname{COSY}$

$9.1 \mathrm{~Hz})$ and $3.01(1 \mathrm{H}, \mathrm{dd}, \mathrm{J}=5.8,13.7 \mathrm{~Hz})$. A coupling constant value of $13.7 \mathrm{~Hz}$ corresponds to a geminal coupling of the $\mathrm{CH} 2$, while a value of $5.8 \mathrm{~Hz}$ corresponds to a ${ }^{3} J_{\text {trans }}$ coupling and 9.1 to a ${ }^{3} J_{\text {cis }}$ coupling with the adjacent neighbour at $\delta 4.76(1 \mathrm{H}, \mathrm{ddd}, \mathrm{J}=5.8,9.1,8.4 \mathrm{~Hz})$ confirmed the proposed relative stereochemistry (Figure $3)$. The COSY correlate to the next proton at $\delta 8.49$ of which both shares a coupling constant value of $8.4 \mathrm{~Hz}$. This finding is in accordance to a presence of an amide moiety adjacent to a tertiary carbon as is also supported by the C13-NMR data and HMBC correlation. Further analyses of the COSY data reveals a present of two isolated neighboring proton having $\delta 5.57(1 \mathrm{H}, \mathrm{d}, \mathrm{J}=2.6 \mathrm{~Hz})$ and $\delta 6.05(1 \mathrm{H}, \mathrm{d}, \mathrm{J}=1.9 \mathrm{~Hz})$. A small coupling constant with the neighboring proton $(\mathrm{J}=1.9 \mathrm{~Hz})$ suggesting that both protons are not directly attached to each other. The HMBC data correlate the protons with a quartenary carbon at $\delta 170.77$ which is also seen by an isolated proton at $\delta 3.78(3 \mathrm{H}, \mathrm{s})$. This isolated proton is in accordance to a resonance of a methoxy group by having a deshielded singlet peak having integration of 63 . A full structure proposed to the compounds confirmed a molecular formula of $\mathrm{C}_{16} \mathrm{H}_{17} \mathrm{NO}_{4}$ which is fit to a 4-methoxy-6-(1'acetamido-2'-phenylethyl)-2H-pyran-2-one, known as 


\section{Discussion}

Pyrophen is an amino acid-pyrone derivative firstly isolated from Aspergillus niger on maize with the crystal configuration was reported in 1990 (Barnes et al., 1990). The spectroscopic data of this compound was published in 2000 (Varoglu and Crews, 2000), which is in accordance to the spectrosopic data of the bioactive compound isolated from this study. However a comparation of the spectral data reveal a huge shift of the signal of the $\mathrm{NH}$-amide to the downfiled region. As already accepted for an exchangeable proton such as $\mathrm{NH}$, unpredictable chemical shift could occurs, especially in the case of different solvent used. Pyrophen was also reported from a saltwater culture of A. niger isolated from a sponge Hyrtios proteus (Varoglu and Crews, 2000), the culture extract of A. niger EN-13 isolated from the inner tissue of the marine brown alga Colpomenia sinuosa, (Zhang et al., 2010) as well as the culture of Alternaria alternata strain D2006, isolated from the marine soft coral Denderonephthya hemprichi (Shaaban et al., 2012). It was interesting to note that Zhang and collaborators can separate pyrophen from its stereoisomer, isopyrophen, which was obtained from A. niger cultured on yellow maize. The compounds are different at the configuration of $\mathrm{C} \alpha$ as the chiral centre. Nevertheless, unlike pyrophen, Zhang et al (2010) described that the isopyrophen has planar structure, which was not the case for our compound.

In terms of bioactivities, phyrophen was reported to have no antimicrobial activities against Escherichia coli, Staphlococcus aureus, Candida albicans, and A. niger (Zhang et al., 2010) and no activities against several cancer cell lines (Varoglu and Crews, 2000). However, this compound was found to be active against $C$.albicans (Shaaban et al., 2012). This discrepancy might be resulted from the difference on the concentration used during their studies. In this study we found that phyrophen exhibited cytotoxicy against T47D cells.Cycle cycle analysis of T47D cells exposed with this compound at $400 \mathrm{ng} / \mathrm{mL}$ resulted in increased $S$ phase cell population. Indeed, $S$ phase arrest is one of mechanisms delaying progression of cell cycle in response to homeostatic regulators or DNA damage and this involves the decrease rate in DNA replication (Kaufmann and Kaufman, 1993). Further examination of its potential as anticancer agent is still under investigation.

In conclusion, these data suggest the potential activity of a phenethyl- $\alpha$-pyrone derivative, pyrophen as anticancer agent. Further investigation on the mechanism on how this compound kills the cancer cells need to be explored.

\section{Acknowledgements}

Authors are grateful to Hibah PUPT Directorate of Research and Community Services, Indonesian Ministry of Research, Technology and Higher Education, Contract No: 27/LPPM/2015 Universitas Gadjah Mada 2015 for providing grant for the work.

\section{References}

Astuti P, Wahyono, Nababan OA (2014). Antimicrobial and cytotoxic activities of endophytic fungi isolated from Piper crocatum Ruiz \& Pav. Asian Pac J Trop Biomed, 4, 643-7.

Barnes CL, Steiner JR, Torres E, et al (1990). Structure and absolute configuration of pyrophen, a novel pryrone derivative of L-phenylalanine from Aspergillus niger. Int. J Peptide Protein Res, 36, 292-6.

Chen H, Daletos G, Okoye F, et al (2015). A new cytotoxic cytochalasin from the endophytic fungus Trichoderma harzianum. Nat Prod Commun, 10, 585-7.

Cui JL, Guo SX, Xiao PG (2011). Antitumor and antimicrobial activities of endophytic fungi from medicinal parts of Aquilaria sinensis, J Zhejiang Univ-Sci B (Biomed \& Biotechnol), 12, 385-92.

do Nascimento AM, Soares MG, da Silva Torchelsen FK, et al (2015). Antileishmanial activity of compounds produced by endophytic fungi derived from medicinal plant Vernonia polyanthes and their potential as source of bioactive substances. World J Microbiol Biotechnol, 31, 1793-800.

IARC (2012) Globocan 2012 : estimated cancer insidence, mortality and prevalence worldwide in 2012. http://globocan. iarc.fr/Default.aspx (available online 16 October 2015).

IARC. (2008).World cancer report 2008. Lyon, International Agency for Research on Cancer. http://www.iarc.fr/en/ publications/pdfs-online/wcr/2008/ (available online 16 October 2015.)

Kaufmann WK, Kaufman DG (1993). Cell cycle control, DNA repair and initiation of carcinogenesis. FASEB J, 7, 1188-91.

Richardson SN, Nsiama TK, Walker AK, et al (2015). Antimicrobial dihydrobenzofurans and xanthenes from a foliar endophyte of Pinus strobus. Phytochemistry, 117, 436-43.

Santiago C, Fitchett C, Munro MH, et al (2012). Cytotoxic and Antifungal Activities of 5-Hydroxyramulosin, a Compound Produced by an Endophytic Fungus Isolated from Cinnamomum mollisimum. Evid Based Complement Alternat Med, $\mathbf{6 8 9 3 1 0 .}$

Shaaban M, Shaaban KA, Abdel-Aziz MS (2012). Seven naphtho- $\gamma$-pyrones from the marine-derived fungus Alternaria alternata: structure elucidation and biological properties. Organic and Medicinal Chemistry Letters, 2, 6.

Varoglu M, Crews P (2000). Biosynthetically diverse compounds from a saltwater culture of sponge-derived Aspergillus niger. J Natural Products, 63, 41-3.

Wang FQ, Tong QY, Ma HR, et al (2015). Indole diketopiperazines from endophytic Chaetomium sp 88194 induce breast cancer cell apoptotic death. Sci Rep, 5, 9294.

WHO (2013). Cancer. http://www.who.int/mediacentre/ factsheets/fs297/en/. (available online 16 October 2015).

Zhang Y, Li XM, Feng Y, et al (2010). Phenethyl- $\alpha$-pyrone derivatives and cyclodipeptides from a marine algous endophytic fungus Aspergillus niger EN-13, Natural Product Research: Formerly Natural Product Letters, 24, 1036-43.

Zhao K, Ping W, Li Q, et al (2009). Aspergillus niger var. taxi, a new species variant of taxol-producing fungus isolated from Taxus cuspidate in China. J Appl Microbiol, 107, 1202-7.

Zheng CJ, Xu LL, Li YY, et al (2013). Cytotoxic metabolites from the cultures of endophytic fungi from Panax ginseng. Appl Microbiol Biotechnol, 97, 7617-25.

Zhu F, Chen G, Wu J, et al (2013). Structure revision and cytotoxic activity of marinamide and its methyl ester, novel alkaloids produced by co-cultures of two marine-derived mangrove endophytic fungi. Nat Prod Res, 27, 1960-4. 